\title{
Bedhaya Sumreg Keraton Yogyakarta
}

\author{
Budi Astuti dan Anna Retno Wuryastuti ${ }^{1}$ \\ Jurusan Tari, Fakultas Seni Pertunjukan, Institut Seni Indonesia Yogyakarta
}

\begin{abstract}
ABSTRAK
Penemuan jejak masa lalu atas keberadaan suatu bentuk budaya, merupakan suatu fenomena yang sangat bernilai. Hal ini dapat melengkapi upaya menelusuri jejak masa lalu dengan ditemukannya susunan materi gerak untuk visualisasi teks tarinya. Namun demikian tafsir kebudayaan atas penemuan jejak masa lalu tersebut tidak bisa meninggalkan faktor kesejarahannya. Dalam kajian teks bedhaya Sumreg ini diketahui susunan materi gerak Bedhaya Sumreg dan keterkaitan makna sumreg dengan pola lantai dan pola gendhing pengiringnya. Pola-pola gendhing yang ditampilkan secara struktural tetap menggunakan tata aturan baku yang sampai sekarang lazim disebut dengan lampah bedhayan. Bedaya yang dianggap pusaka ini diungkapkan tidak hanya materi tekstualnya saja tetapi juga mencakup materi kontekstualnya.
\end{abstract}

Kata kunci: bedhaya Sumreg, tari Yogyakarta, tari pusaka.

\section{ABSTRACT}

Bedhaya Sumreg of Yogyakarta Palace. The discovery of the past existence traces of a culture is trully a valuable phenomenon. This may complete the efforts to trace the past with the discovery of the structure of motion for the text visualization of a dance. However, the interpretation of culture on the discovery of traces of the past cannot abandon the historical factor. The textual study of Bedhaya (traditional dance) Sumreg has identified the motional structure of Bedhaya Sumreg and the linkage of Sumreg meaning with the floor pattern and gendhing (the accompanied music). The patterns of gendhing structurally shown remain applying predefined set of rules, commonly known as lampah bedhayan (rules in dancing). Bedhaya (traditional dance) is considered a heritage and is revealed not only its textual material but also the contextual one.

Keywords: bedhaya Sumreg, Yogyakarta dance, dance heritage.

\section{Pendahuluan}

Keberadaan pelembagaan tari klasik gaya Yogyakarta tidak dapat dipisahkan dengan keraton atau istana Yogyakarta dan Sultan sebagai penyelenggara, pemelihara, dan sekaligus bagaimana seni pertunjukan itu diproduksi dan dikembangkan. Pelembagaan tari klasik gaya Yogyakarta telah dimulai sejak pemerintahan Sultan Hamengku Buwono I, di antara pelembagaan tari klasik gaya Yogyakarta itu antara lain pelembagaan tarian yang disebut tari "Bedhaya". Keberadaan pelembagaan tarian Bedaya di lingkungan keraton Yogyakarta, nampaknya merupakan kelanjutan dari genre yang berakar dari Mataram Baru. Dalam catatan perjalanan yang ditulis oleh Rijklof van Goens sekitar tahun 1648 sampai 1654 ketika mengunjungi Mataram, antara lain menyaksikan tarian itu (Graaf 1956: 235-238; lihat juga Soedarsono, 1984: 15).

Kehadiran pelembagaan tari Bedhaya di keraton Yogyakarta bukan hanya sekedar sebuah bentuk organik penataan gerak semata, tetapi tarian ini mengandung makna yang cukup kompleks yang bersifat supraorganik, yang terungkap dari sisi bentuk lahiriah maupun batiniah. Sebagai media pewarisan budaya Jawa, tarian ini memiliki tarian historis, sosiologis, politis, maupun nilai-nilai pendidikan yang terkandung di dalamnya. Sri Sultan Hamengku Buwono I sampai Sri Sultan Hamengku Buwono X secara berkesinambungan memimpin keraton Yogyakarta. Masing-masing Sultan memiliki konsep tersendiri ketika menciptakan sebuah tarian, sehingga sampai saat ini yang dirasakan adalah dinamika yang berbedabeda pada masa kepemimpinannya. Keberadaan tari Bedhaya di dalam keraton bukanlah sekedar bentuk tarian untuk kepentingan pertunjukan saja, tetapi lebih berfungsi ritual sebagai bentuk regalia atau pusaka kerajaan untuk menunjukkan tanda-tanda kebesaran raja (Hadi, 2001: 76 -91).

Sebagai teks tari, Bedhaya dapat dimengerti sebagai sebuah bentuk budaya di mana makna yang

1 Alamat korespondensi: Prodi Tari ISI Yogyakarta. Jalan Parangtritis KM 6,5 Sewon, Yogyakarta 55001. E-mail: budiastuti@ isi.ac.id 
terkandung di dalamnya tidak saja terbatas hanya pada materi tekstualnya, tetapi juga mencakup seluruh kontekstualnya, Secara ideal, materimateri yamg bersifat tekstual dapat berupa motif gerak, susunan dan struktur komposisi gerak, motif-motif gerak,gaya karakteristik, pola lantai, gaya karakteristik, level, rias dan busana, dan iringan. Hal-hal yang bersifat wacana atau fenomena atas suatu bentuk budaya dapat dikategorikan pada tingkat pengamatan kontekstual.

Penemuan jejak masa lalu.atas keberadaan suatu bentuk budaya yang menjadikannya sebagai pusaka budaya merupakan suatu fenomena yang sangat bernilai, khususnya di kalangan masyarakat tertentu. Sudah barang tentu penemuan yang demikian tadi tidak bisa meninggalkan faktor kesejarahan.Penelusuran masa lalu tersebut tidak lain adalah merupakan suatu tahap awal dari keseluruhan sistem dalam pelestarian pusaka alam dan budaya. Upaya penelusuran ini merupakan perwujudan keikutsertaan dalam menanggapi Piagam Pelestarian Pusaka Indonesia 2003 sebagai salah satu agenda dasawarsa Pelestarian Pusaka Indonesia 2004 - 2013 (Artha, Ahimsa Putra, 2004: 18-19)

Bedhaya Sumreg merupakan salah satu tarian pusaka yang mempunyai sejarah cukup panjang yaitu pada zaman pemerintahan Mataram sebelum terpecah menjadi Kasunanan Surakarta dan Kasultanan Yogyakarta. Melalui studi pustaka berupa manuskrip yang ditulis pada masa pemerintahan Sri Sultan Hamengku Buwono VI (1855 - 1877) ditemukan keterangan bahwa Bedhaya Sumreg merupakan karya Susuhunan Paku Buwono I setelah perjanjian Giyanti pada tahun 1755.

Kemunculan Bedhaya Sumreg pada awalnya sebagai upaya mutrani (menduplikasi) tarian Bedhaya Ketawang karya Sultan Agung Prabu Hanyakrakusuma (Prajapangrawit, 1990: 75). Menurut Prajapangrawit gendhing pengiring Bedhaya Sumreg hampir mirip dengan Gendhing Ketawang yang mengiringi Bedhaya Ketawang. Sehubungan dengan itu iringan Bedhaya Sumreg disebut dengan istilah Gendhing Ketawang Alit, sementara itu Gendhing Ketawang karya Sultan Agung Prabu Hanyakrakusuma lazim disebut dengan Gendhing Ketawang Ageng. Selain kedua bedhaya pusaka tersebut, terdapat bedhaya-bedhaya lain seperti Bedhaya Gadhung Mlathi, Bedhaya
Semang, Bedhaya Rambu dan Bedhaya Babarlayar (Papenhuijzen, 1992: 48).

Akibat pecahnya kerajaan Mataram Baru, bedhaya-bedhaya gendhing Semang, Rambu, dan Babar Layar ikut menjadi bagian kasultanan Yogyakarta (Prajapangrawit, 1990: 69 - 70), dan hingga kini Bedhaya Semang tetap dianggap sebagai bedhaya pusaka, sedangkan Kasunanan Surakarta sampai sekarang masih melestarikan Bedhaya Ketawang sebagai pusaka budayanya. Keberadaan Bedhaya Sumreg, dan Bedhaya Gadhungmlathi kurang mendapat perhatian.Kedua bedhaya pusaka ini mengalami ketidakjelasan terkait dengan keberadaannya. Hal ini tampaknya berkaitan dengan prinsip dasar yang dianut Kasultanan Yogyakarta dan Kasunanan Surakarta, yaitu segala bentuk hasil budaya pada zaman Mataram ikut menjadi bagian dari Kasultanan Yogyakarta dengan prinsip pelestariannya, sedangkan Kasunanan Surakarta mempunyai prinsip pembaharuan atas segala hasil budayanya, bahkan cenderung melakukan inovasi (Soedarsono, 1997:22-25). Bila demikian halnya sudah selayaknya bila Bedhaya Sumreg yang semula adalah karya Paku Buwono I, pada akhirnya diwarisi Kasultanan Yogyakarta.

Kata sumreg sebagai suatu istilah mempunyai makna ribut, gempar, gaduh, dan hiruk pikuk (Prawiroatmodjo, 1985:218), kegaduhan tersebut tersurat dalam penggalan pasindhenan atau lagu yang dibawakan sebagai berikut:

'Sumreg kang bala lumaris bubare saking Ngayugya asri tinon gegamane akeh warnane kang bala

wong sabarang lan wong Jawaswarane atri gumuruh

kadi ombaking samodra.

Tuhu yen prabu tur luwih mangrenggani surya candra

lir toya mili danane putus sandining upaya kedhep ing wadyabala ana lana andon pupuh

anggempur ing parangmuka

Bisikanira narpati Jeng Sultan Mengku Buwono senopati ngajurite lir piturun saking swarga mangke Sri Naranata nitih kuda rekta gempung Kyai Jaya Kumala” 
(Serat Pasindhenan Kelangenan Dalem Bedhaya Sumreg, B 23, tt, yang juga dikutip oleh Brakel-Papenhuijzen, 1992: 176-177)

Secara garis besar teks itu memiliki arti, bahwa ramainya tentara yang berjalan dari Jogjakarta dengan berbagai persenjataan yang banyak mewarnai, suaranya keras laksana ombak samudera. Kekuatan raja menimbulkan ilmu tipu daya saat menghadapi musuh, sehingga membuat senantiasa disegani oleh bala tentaranya, bahkan dikenang untuk selamanya. Tersebutlah raja Sri Sultan Hamengku Buwono I dengan kegemarannya menaiki kuda Kyai Jaya Kumala.

Pada umumnya tari bedhaya dipandang sebagai suatu tarian yang keramat dan unik. Di Kasunanan Surakarta dan Kasultanan Yogyakarta, tarian ini biasanya dipergelarkan pada peristiwaperistiwa penting seperti halnya pada upacara besar. Pergelaran tari bedhaya lebih difungsikan sebagai sarana upacara ritual tertentu di dalam lingkungan istana. Pada zaman kerajaan Mataram, Bedhaya Sumreg ditampilkan pada saat perayaan ulangtahun raja, Bedhaya Gadhungmlathi ditampilkan pada saat perayaan hari lahir pawukon raja dan hari ulangtahun permaisuri, sementara Bedhaya Ketawang dipergelarkan pada saat hari ulang tahun kenaikan tahta raja (Pradjapangrawit, 1990: 79)

Dalam penulisan ini kajian tekstual yang dimaksud mencakup motif gerak, susunan dan struktur, gaya karakteristik, serta pola lantai. Adapun kajian kontekstual Bedhaya Sumreg dapat dimengerti melalui kesejarahan, gejolak politik, serta zaman dan kebudayaan yang melingkupinya. Hal yang menarik adalah dengan merunut apa yang tersurat dan tersirat dari Wedhapradangga, Serat Kandha Kelangenan Dalem Bedhaya Sumreg, maupun Serat Pasindhenan Bedhaya Srimpi lan Candran Warna-warni, tampaknya ada benang merah yang melatarbelakangi keberadaan Bedhaya Sumreg. Penelitian yang berpijak pada sebuah naskah tari yang berupa manuskrip koleksi perpustakaan Kridha Mardawa dan Widyabudaya keraton Yogyakarta ini memuat susunan gerak, pola lantai dan pola gedhing pengiringnya. Berdasar penjelasan di atas maka dalam penulisan ini akan diuraikan bagaimana susunan atau komposisi tari Bedhaya Sumreg, dan adakah makna dan nilai yang terungkap dibalik tarian itu.

\section{Pengertian Bedhaya}

Bedhaya merupakan salah satu bentuk tari istana, dengan koreografi kelompok yang biasanya ditarikan oleh para penari puteri, meskipun pada kenyataannya ada pula yang ditarikan oleh penari putera yang dikenal dengan Bedhaya Kakung. Pada umumnya jumlah penari ada sembilan orang dengan rias dan busana yang sama. Bedhaya memiliki tata dan aturan penyusunan yang khas, yang secara baku telah memberi ciri dan ikatan tertentu pada setiap pola susunannya. Bedhaya yang memiliki makna simbolik yang cukup dalam, masih dilestarikan dan berkembang di Kasunanan Surakarta dan Kasultanan Yogyakarta. Bentuk koreografi Bedhaya pada umumnya bersifat menyatu, artinya motif menuju komposisi kelompok Sembilan penari selalu menyatu sesuai dengan peran dan karakter yang dibawakan. Adapun peran dalam bedhaya sesuai dengan karakternya seperti yang ditunjukkan gambar pola lantai dasar sebagai berikut

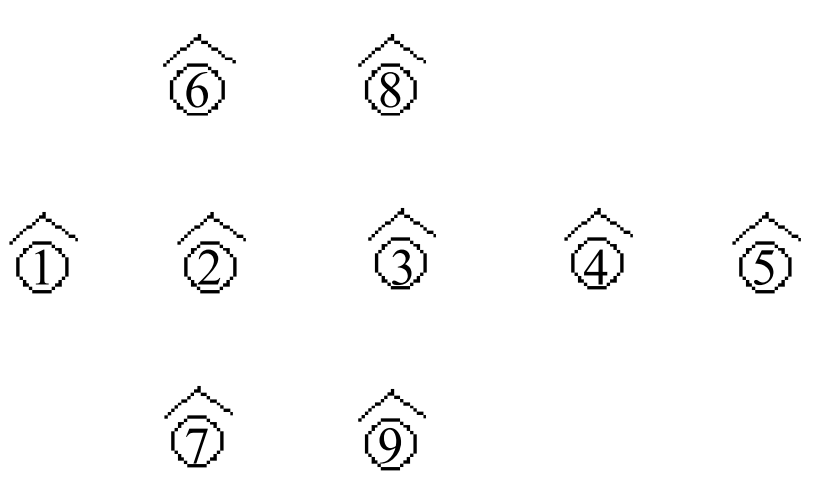

Gambar 1: Pola lantai dasar bedhaya

Keterangan:

1. Endhel (Endhel Pajeg)

2. Batak

3. Jangga

4. Dhadha

5. Buntil

6. Apit Ngajeng

7. Apit Wingking

8. Endhel Wedalan Ngajeng

9. Endhel Wedalan Wingking 
Dalam tari gaya Yogyakarta kesembilan penari tersebut terdiri dari lima penari sebagai lajur dan empat penari lain sebagai srimpi. Melalui apa yang tersurat pada bedhaya memberi gambaran bahwa empat penari bedhaya yang tidak termasuk lajur atau baris di tengah itu adalah serimpi. Suharto (1991, 37 - 54) menegaskan empat penari yang ada di pinggir adalah Serimpi sementara lima penari yang ada di tengah sebagai Bedhaya-nya. Hal tersebut merupakan pemahaman yang secara konseptual tidak dapat dipisahkan. Oleh karena itu meskipun dalam hal tertentu serimpi dan bedhaya merupakan sesuatu yang berbeda, namun kiranya kedua bentuk komposisi tari ini bisa dikelompokkan menjadi satu genre tersendiri.

Lima penari lajur yaitu Endhel Pajeg, Batak, Jangga, Dhadha, dan Buntil sebagai penggambaran kepala dan badan manusia, empat penari serimpi yaitu Endhel Wedalan Ngajeng, Endhel Wedalan wingking, Apit Ngajeng dan Apit wingking sebagai penggambaran anggota badan yang terdiri dari tangan kanan, tangan kiri, kaki kanan, dan kaki kiri (Suharto,1999: 36). Pendapat lain mengenai bedhaya menurut K.P.H. Brongtodiningrat adalah sebagai berikut:

Bedhaya sanga punika tegesipun hanggotaning manungsa punika

dipun praboti bolongan sanga, inggih punika mripat kalih, hirung kalih, kuping kalih, tutuk setunggal, ,jubur setunggal sarta

kelamin setunggal (Yayasan Siswa Among Beksa, 1981: 20)

(Bedhaya dengan Sembilan penari ini mengandung makna bahwa manusia memiliki

sembilan lubang yaitu mata dua, hidung dua, telinga dua, mulut satu, dubur satu, dan alat kelamin satu)

Bedhaya sebagai salah satu bentuk tari tradisi keraton Jawa yang pada umumnya bersifat abstraksimbolis mempunyai ciri simbolis representatife seperti pada tema-tema geraknya. Pengolahan pola lantai merupakan suatu pola yang berangkaian tetap dan teratur. Demikian pula halnya di dalam letak kedudukan penari-penarinya. Penyusunan pola lantai pada dasarnya ditata bukan sematamata untuk mencari efek dramatis, tetapi didasarkan pada keyakinan tertentu yang ada pada masyarakat Jawa. Pola lantai yang dibentuk oleh Sembilan orang penari bedhaya tersebut konfigurasinya berbeda-beda, seperti ditunjukkan dalam gambar 2. Pola lantai tersebut membentuk (a) rakit lajur, (b) rakit ajeng-ajengan, (c) rakit iring-iringan, (d) rakit mlebet lajur, dan (e) rakit tiga-tiga.

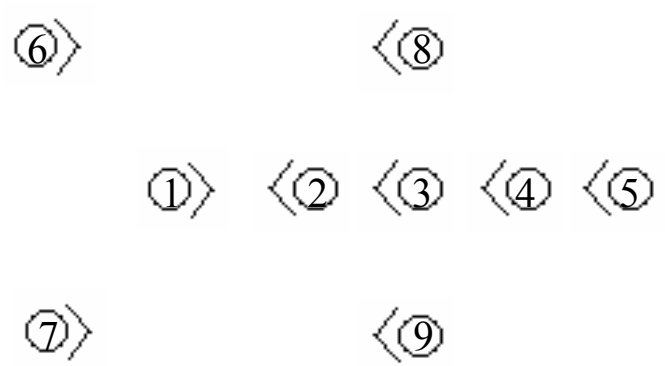

(b) 


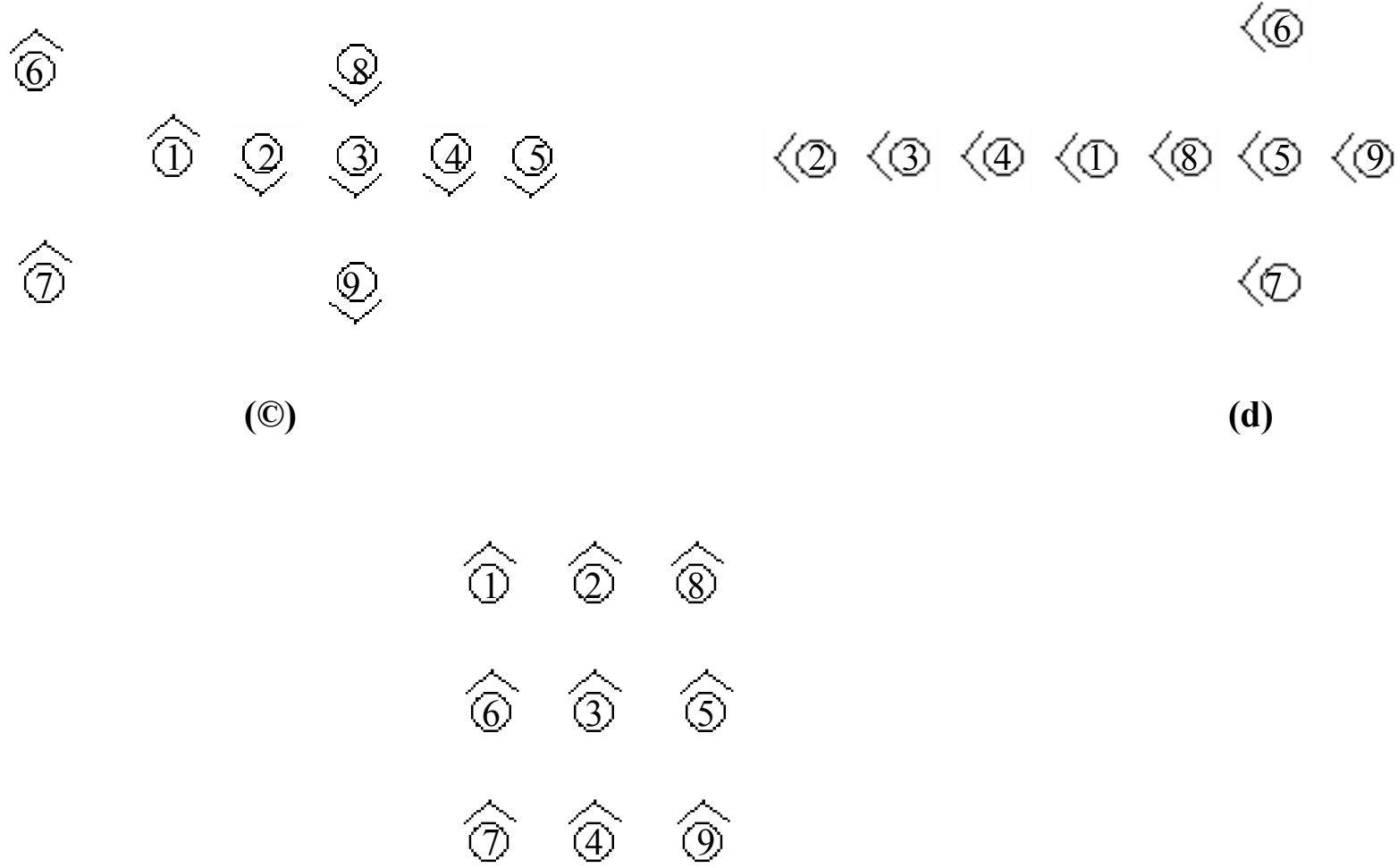

Gambar 2: Macam-macam pola lantai bedhaya

Sebagai suatu siklus, maka pola lantai dan formasi penari dalam tari bedhaya sekaligus menggambarkan siklus pemikiran manusia, yang diawali dari rakit lajur sebagai lambang kelahiran manusia, rakit ajeng-ajengan dan rakit iringiringan melambangkan adanya konflik, diakhiri dengan pencapaian kesadaran dan kemanunggalan yang ditampilkan dalam rakit tiga-tiga. Selain rakit-rakit pokok di atas, dalam bedhaya terdapat rakit gelar yang secara baku ditampilkan sesudah

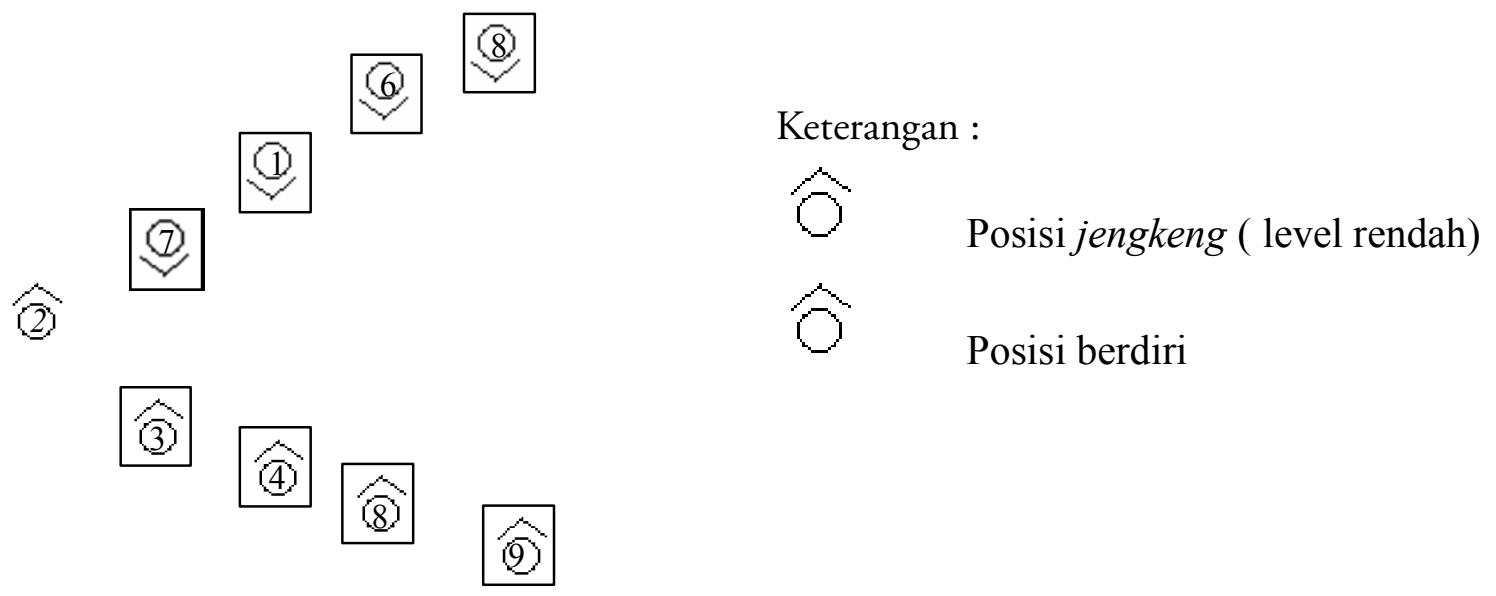

rakit ajeng-ajengan, dan rakit iring-iringan. Inti cerita di dalam bedhaya termuat di dalam rakit gelar tersebut.

Rakit gelar bedhaya Sumreg memuat cerita kepahlawanan Pangeran Mangkubumi kala mempersiapkan bala tentaranya menghadapi musuh. Tokoh Mangkubumi diperankan oleh Batak seperti ditunjukkan dalam gambar 3 di bawah ini

Gambar 3: Pola lantai rakit gelar bedhaya Sumreg 
Nama bedhaya pada umumnya disebut dengan menggunakan nama gendhing pengiringnya, seperti bedhaya Babarlayar, bedhaya Pangkur, bedhaya Bondet, bedhaya Semang dan lainlain. Ciri spesifik pada iringan bedhaya dalam mengungkapkan efek dramatis, dinamika, dan menampilkan tokoh tertentu, biasanya tertata indah secara simbolik dalam bentuk gerongan. Dengan kata lain, pada umumnya iringan bedhaya selalu berkonotasi dengan gendhing lampah bedhayan yang mempunyai gerongan yang khas. Secara struktural, pola gendhing pengiring bedhaya memiliki tata aturan yang baku sebagai berikut

1. Bagian Awal

a. Lagon untuk mengiringi penari masuk ke
area pertunjukan dengan rakit lajur

b. Gendhing Sabrangan (gendhing-gendhing Gati irama I) digunakan untuk kapangkapang majeng, kemudian suwuk

c. Lagon

d. Kandha

2. Bagian pokok

a. Bawa sekar

b. Katampen gendhing Ageng atau gendhing Tengahan yang terdiri dari Merong lalu Ndawah

c. Minggah Ladrang

d. Bawa sekar

e. Katampen Ketawang dengan pola lantai rakit gelar

3. Bagian Akhir

a. Lagon, mengiringi penari selama proses perubahan dari rakit tiga-tiga menjadi rakit lajur kembali.

b. Gendhing Sabrangan (gendhing-gendhing Gati irama I) digunakan untuk kapangkapang mundur

c. Lagon untuk keluar dari arena pentas.

Sesuai dengan kepentingannya, bedhaya pada awalnya selalu dipentaskan di dalam keraton. Berkenaan dengan tempat yang dipakai sebagai arena pertunjukan, dan terkait dengan keberadaan bedhaya yang merupakan tari upacara, maka penyelenggaraannya menggunakan tempat satu lantai dengan tempat duduk raja.

\section{Kemunculan Bedhaya Sumreg}

Mataram (1576 - 1745) merupakan pusat kekuasaan regional yang menjadi titik fokus dari kekuasaan raja di Jawa ( Ricklefs, 2002: 12 -13). Penguasa pertama Mataram adalah Panembahan Senopati Ingalaga (1576 - 1603). Semasa penguasaan Panembahan Senapati yang pada masa mudanya bernama Sutawijaya, banyak dilalui serangkaian peperangan, terutama melawan kekuasaan-kekuasaan pesisir timur serta campur tangan Belanda yang memainkan peran dalam sejarah internal Jawa (Ricklef, 2002: 14-15).

Panembahan Senapati digantikan oleh putranya yang bernama Raden Mas Jolang atau Panembahan Adiprabu Nyakrawati (1603-1613). Masa pemerintahannya bukan saja disibukkan dengan perang melawan pemberontak dan penguasa pesisir yang menyainginya, melainkan juga pembangunan berbagai gedung dan beteng keraton di Kotagede (Ricklefs, 2002: 16). Beliau berjasa dalam bidang kebudayaan dengan berusaha menyusun sejarah negeri Demak serta menulis serat Suluk Wijil dan Serat Nitisruti. Suluk Wijil berisi wejangan mistik Sunan Bonang kepada abdi raja Majapahit. Sedangkan Serat Nitisruti berisi tentang tuntutan budi pekerti luhur dan kandungan mistik (Purwadi, 2001:20)

Panembahan Adiprabu Nyakrawati yang dikenal dengan Panembahan Krapyak digantikan oleh putranya yang dikenal dengan Sultan Agung Nyakrakusuma. Beliau mengendalikan Mataram tahun 1613-1645 sebagai tokoh yang agung dalam sejarah Jawa. Sultan Agung menaklukkan pangeran-pangeran Jawa yang membangkang dalam serangkaian peperangan, yang puncaknya pada pengepungan Surabaya pada tahun 1625 (Ricklefs, 2002: 17). Tidak hanya dalam bidang politik, dalam bidang seni pun Sultan Agung mempunyai perhatian yang cukup besar. Pada masa pemerintahannya diciptakan bedhaya Ketawang yang dipergelarkan untuk memperingati ulangtahun kenaikan tahta raja. Selain bedhaya Ketawang diciptakan pula bedhaya pusaka lainnya seperti bedhaya Gadhungmlathi, bedhaya Babarlayar, dan bedhaya Rambu. Selain sebagai raja, Sultan Agung juga berpredikat sebagai pujangga. Karya yang terkenal yaitu serat Sastra Gendhing yang berisi budi pekerti luhur, mistik, keselarasan lahir batin, dan serat Nitipraja yang berisi tentang moralitas penguasa dalam 
menjalankan kewajibannya, etika bawahan kepada atasan, hubungan rakyat dengan pemerintah, agar tatanan masyarakat dan Negara dapat menjadi harmonis (Purwadi, 2001:21). Setelah wafatnya Sultan Agung, tidak semua dinasti penerusnya dapat menjadi pemimpin yang agung.

Pemerintahan Susuhunan Amangkurat I (1645 -1677) pengganti Sultan Agung Hanyakrakusuma, merupakan bencana (Ricklefs, 2002: 23). Beliau memulai kekuasaannya dengan serangkaian pembantaian. Perpecahan muncul di dalam keraton dan seluruh Negara. Amangkurat I berusaha menguasai seluruh perdagangan pantai. Keraton jatuh ke tangan pemberontak pada tahun 1677, dan Amangkurat I wafat dalam pelarian. Kedudukan Amangkurat I digantikan oleh Pangeran Adipati Anom atau Amangkurat II (1677-1703).Keterlibatan VOC dalam urusan intern kerajaan Mataram semakin kuat. Permintaan bantuan Amangkurat II kepada VOC dalam menumpas pemberontak merupakan awal berkurangnya kekuasaan Mataram.

Pengganti Amangkurat II adalah Mangkurat Mas atau Amangkurat III (1703-1708).Masa pemerintahan Amangkurat III kurang disukai dalam lingkungan kerajaan Mataram. Kekuasaannya direbut oleh pamannya, Pangeran Puger yang kemudian bergelar Sunan Paku Buwono I. Peristiwa ini disebut dengan perang suksesi Jawa I (Purwadi, 2001: 44). Sunan Paku Buwono I yang memerintah pada tahun 1704-1719, menciptakan bedhaya Sumreg yang ditampilkan pada saat ulangtahun raja. Kemunculan bedhaya Sumreg pada awalnya sebagai upaya mutrani (menduplikasi) bedhaya Ketawang (Pradjapangrawit, 1990: 79). Iringan bedhaya Sumreg hampir mirip dengan bedhaya Ketawang. Oleh karena itu iringan bedhaya Sumreg disebut dengan istilah gendhing Ketawang alit, sedangkan iringan bedhaya ketawang disebut dengan gendhing Ketawang Ageng.

Pada masa pemerintahan Sunan Pakubuwono II dan Sunan Pakubuwono III, terdapat barisan oposisi yang sangat kuat, yaitu Pangeran Mangkubumi. Ketidaksenangan Pangeran Mangkubumi terhadap campur tangan Belanda, membuatnya harus melakukan perlawanan antara tahun 1746-1755. Pertikaian keluarga ini diakhiri dengan perjanjiyan Giyanti, yang dikenal dengan Babad Paliyan Negari, yang membelah Mataram menjadi dua yaitu Surakarta dan Yogyakarta.
Setelah kerajaan Mataram mengalami kemunduran secara politik, justru pustaka sastra Jawa justru mengalami perkembangan yang sangat pesat dengan lebih diperhatikannya bidang sastra budaya. Namun demikian akibat pecahnya Mataram, muncul kemelut soal pembagian segala bentuk hasil budayanya. Hal tersebut kemungkinan berkaitan dengan prinsip dasar Kasultanan Yogyakarta dan Kasunanan Surakarta. Bahwasanya segala bentuk hasil budaya pada jaman Mataram ikut menjadi bagian dari Kasultanan Yogyakarta dengan prinsip pelestariannya, sedangkan Kasunanan Surakarta mempunyai prinsip pembaharuan atas segala hasil budayanya, bahkan cenderung melakukan inovasi (Soedarsono,1997: 22-25). Bedhayabedhaya gendhing Semang, Rambu, dan Babarlayar ikut menjadi bagian dari Kasultanan Yogyakarta, sedangkan Kasunanan Surakarta sampai sekarang masih melestarikan bedhaya Ketawang sebagai pusaka budayanya. Keberadaan bedhaya Sumreg dan bedhaya Gadhungmlathi pada mulanya mengalami ketidakjelasan. Bila demikian halnya bisa diinterpretasikan bahwa bedhaya Sumreg pada akhirnya diwarisi oleh kasultanan Yogyakarta.

\section{Bedhaya Sumreg di Keraton Yogyakarta}

Perjanjian Giyanti yang dikenal dengan sebutan Babad Paliyan Negari telah membagi Mataram menjadi dua yaitu Kasunanan Surakarta dan Kasultanan Yogyakarta. Pecahnya Mataram tidak menghentikan gaya tarinya (beksan Mataram) dengan terus dilestarikan oleh Sri Sultan Hamengku Buwono I.Gaya Mataram tersebut akhirnya menjadi cikal bakal lahirnya tari klasik gaya Yogyakarta. Bedhaya Sumreg di keraton Yogyakarta kiranya turut andil dalam upaya pelestarian beksan Mataram. Hal ini merunut pada pewarisan budaya Mataram pasca perjanjian Giyanti. Beksan Mataram yang menjadi sumber perkembangan tari klasik gaya Yogyakarta, secara garis besar terbagi dalam tiga periode. (1) Periode pertumbuhan (mulai jaman Sri Sultan Hamengku BuwonoI sampai Sri Sultan Hamengku Buwono VII); (2) Periode pembakuan (mulai jaman Sri Sultan Hamengku Buwono VII sampai tahun 1960); (3) Periode pengembangan/pembaharuan (mulai tahun 1960 sampai sekarang) (Suharto, 1981:110-112) 
Periodisasiyang terjadiberdasarkan perubahanperubahan yang mencolok di setiap masanya.

\section{Periode pertumbuhan}

Bedhaya Sumreg sebagai salah satu bentuk tari gaya Yogyakarta lahir bersama tumbuhnya Kasultanan Yogyakarta pada masa pemerintahan Sri Sultan Hamengku Buwono I. Melalui studi pustaka yang berupa manuskrip yang ditulis pada masa pemerintahan Sultan Hamengku Buwono IV, ditemukan keterangan bahwa bedhaya Sumreg di bawa ke Kasultanan Yogyakarta oleh Sri Sultan Hamengku Buwono I setelah mengadakan penyerbuan menuju Surakarta diantarkan bala tentaranya. Keterangan tersebut tertuang dalam awal kandha dari bedhaya Sumbrek. Meskipun dalam kandha tertulis sumbrek, keraton Yogyakarta lazim menggunakan istilah sumreg untuk menyebut bedhaya pusaka ini. Hal yang demikian melihat pada kesamaan makna dari kedua istilah tersebut di atas. Melalui penelusuran jejak masa lalu bedhaya Sumreg lewat studi pustaka manuskrip, ditemukan juga adanya keterangan bahwa pada masa Hamengku Buwono III telah berupaya merekonstruksi bedhaya tersebut. Dalam upaya pada waktu itu, selain mempersiapkan notasi tari dengan segala catatan pola lantai yang diperlukan, ditemukan juga suatu usaha pengembangan atas penataan iringannya.

Bedhaya Sumreg yang semula (jaman Mataram) menggunakan gamelan Lokananta yang terdiri dari kemanak, kethuk, kenong, kendang, dan gong, pada manuskrip terdapat adanya catatan pasindhen serta gangsa (Serat Kandha KelangenanDalem Bedhaya Sumbreg B/S 7). Keterangan tersebut dapat menyatakan bahwa ada upaya melengkapi kesederhanaan gamelan yang semula digunakan. Perkembangan tersebut tanpa mengurangi nilainilai dasar yang sudah ada. Bedhaya Sumreg di keraton Yogyakarta dipergelarkan pada upacara besar sebagai pusaka yang melengkapi sarana upacara ritual kenaikan tahta raja, dalam hal ini adalah pada masa Sri Sultan Hamengku Buwono IV.

\section{Periode Pembakuan.}

Dalam periode ini beksan Mataram mencapai tahap yang secara kualitatif menjadi ukuran mutu dari perkembangan joged Mataram. Mulai dari tata busana sampai dengan penambahan ragam tari dan penyempurnaan gerak. Periode ini merupakan titik mula dari periode baru, bahkan seni musik dikembangkan untuk mengiringi beksan. Usaha mengembangkan dan menyebarluaskan tari ke luar tembok istana juga dimulai pada masa pemerintahan Sri Sultan Hamengku Buwono VII. Kridha Beksa Wirama, Irama Citra, Siswa Among Beksa, adalah organisasi/ paguyuban yang berkembang di luar istana tempat mempelajari, menggali, memelihara, dan mengembangkan kesenian klasik gaya Yogyakarta (Wibowo,ed. 1981: 226-227).

Sejak jaman Sri Sultan Hamengku Buwono VII, bedhaya Sumreg tidak terdengar lagi gaungnya. Meski demikian, bedhaya sebagai bagian dari perkembangan tari gaya Yogyakarta yang secara politis merupakan sebuah warisan dari masing-masing pemerintahan terutama pada masa kerajaan, tetap dipandang sebagai simbol legitimasi raja.

\section{Periode Pengembangan/pembaharuan}

Dalam periode ini lahir corak garapan tari yang digabung dengan penampilan unsur-unsur teater modern yang kemudian disebut sendratari (seni drama tari). Perkembangan tari lewat unsurunsur pendukungnya mulai dikenal dan dipelajari dalam periode ini.

Bedhaya Sumreg sebagai salah satu bedhaya pusaka dapat dimengerti sebagai suatu bentuk budaya, dimana makna yang terkandung di dalamnya tidak saja terbatas pada materi tekstualnya, tetapi lebih dari itu juga mencakup seluruh kontekstualnya. Keraton Yogyakarta dan barangkali juga Surakarta, mengembangkan suatu pandangan sejarah resmi yang menjadikan eksistensi dua keraton tidak bertentangan dengan tradisi-tradisi masa lalu (Ricklefs, 2002:285)

\section{Bedhaya Sumreg Sebagai Teks}

Kehadiran bedhaya di keraton Yogyakarta bukan hanya sekedar sebuah bentuk penataan gerak semata, tetapi mengandung makna yang cukup kompleks, yang terungkap dari sisi lahiriah secara organik, tetapi juga batiniah atau supra organiknya. Sebagai media pewarisan budaya Jawa, makna historis, politis, dan muatan nilai-nilai pendidikan, nampak terkandung di dalamnya. Bedhaya yang merupakan warisan dari masing-masing masa pemerintahan, secara politis sering dipandang sebagai suatu symbol legitimasi 
raja. Bedhaya yang bila dianggap sebagai pusaka, diharapkan mampu menambah kekuatan dan kekuasaan raja. Oleh karena itu secara historis di keraton Yogyakarta setiap sultan yang sedang memerintah berusaha menciptakan sebuah tarian bedhaya.

Sebuah teks merupakan sesuatu yang bisa dibaca dan ditafsirkan. Kesenian sebagai teks dengan segala peristiwa di dalamnya merupakan sesuatu yang bisa dibaca dan ditafsirkan dengan bebas seperti halnya membaca sebuah teks (Ahimsa Putra, 1998: 20). Penafsiran bebas atas teks harus tetap menggunakan konsep atau sumber acuan yang dapat dipercaya dan bisa memberikan tafsir yang tepat. Sebagai teks tari bedhaya terlahir sebagai refleksi dari keseluruhan kebudayaan masyarakat yang bersangkutan. Bedhaya Sumreg dengan segala konflik di dalamnya, merupakan kesatuan teks yang keberadaannya merupakan objek yang akan dibaca, serta ditafsirkan melalui makna simbolis yang terungkap lewat hasil tafsirannya. Penafsiran akan teks selalu diikuti oleh teks yang lain, dan hal inilah yang kemudian disebut dengan konteks (Djoharnurani, 1999:11). Kajian teks dalam tulisan ini tetap menunjuk pada pemilihan konsep atau sumber acuan yang dapat dipercaya agar bisa memberikan tafsiran yang tepat.

Objek tulisan ini adalah sebuah tari dalam genre bedhaya.Seperti yang telah diuraikan di depan, materi yang bersifat tekstual secara ideal berupa motif gerak, susunan dan struktur, gaya karakteristik, pola lantai, level, rias busana, property, dan iringan. Selain itu juga tata lampu, tata panggung, serta konsep pemanggungannya. Hal-hal yang bersifat wacana atau fenomena dapat dikategorikan pada tingkat pengamatan kontekstual. Kajian kontekstual pada bedhaya dimengerti pada zaman dan kebudayaan yang melingkupinya, selain kesejarahan, sosial kemasyarakatan, bahkan politik, dan nilai-nilai pendidikan lainnya. Untuk membahas masalah teks dalam tulisan ini berpijak pada manuskrip koleksi perpustakaan Kridha Mardhawa dan Widya Budaya keraton Yogyakarta. Manuskrip tersebut memuat susunan gerak, pola lantai, dan pola gendhing pengiring bedhaya Sumreg. Manuskrip tersebut juga memuat data bahwasanya bedhaya Sumreg ini ditulis pada masa pemerintahan Sri Sultan Hamengkubuwono VI (1855-1877). Meskipun demikian upaya penulisan oleh Sri
Sultan Hamengku Buwono VI ini adalah suatu upaya pelestarian atas karya pendiri kasultanan Yogyakarta, Sri Sultan Hamengku Buwono I.

Kajian teks bedhaya Sumreg sebagai salah satu bedhaya di keraton Yogyakarta, dapat dimengerti sebagai bentuk budaya seperti yang terkandung di dalam materi tekstualnya. Berdasar pada manuskrip koleksi perpustakaan Kridha Mardawa dan Widya Budaya ini, di dapat materi-materi tekstual yag kiranya dapat mendukung penelusuran jejak masa lalu atas suatu hasil budaya kerajaan di kasultanan Yogyakarta.

\section{Motif Gerak dan Pola Lantai}

Gerak sebagai elemen dasar tari merupakan hal yang penting dalam serangkaian bentuk tari. Rangkaian motif-motif gerak dalam bedhaya Sumreg secara umum terdapat dalam tari bedhaya gaya Yogyakarta lainnya. Demikian halnya dengan pola lantainya.

Motif gerak tari bedhaya Sumreg dapat dikategorikan dalam dua kategori, yaitu motif gerak milir dan motif gerak mandeg, atau gerak yang dilakukan berpindah tempat dan gerak yang dilakukan di tempat (Suharti, 1983: 16). Kedua kategori ini diperkuat lagi dengan penggunaan gerak yang mendominasi pada gerak dasarnya, seperti dalam motif gerak wedhi kengser yang didominasi oleh kaki, dan motif gerak ukel tawing yang didominasi oleh tangan.

Motif gerak dalam bedhaya Sumreg yang termasuk dalam kategori motif gerak mandheg antara lain: sembahan sila, lembehan, gidrah, ngenceng lembehan, ngenceng encot, ngenceng jengkeng, bango mate, ukel tawing, duduk wuluh, ongkek tawing, gudhawa asta minggah, ngunduh sekar, ulap-ulap, ngrudha, atur-atur, pucang kanginan. Motif-motif gerak tersebut biasanya tidak menggunakan langkah kaki. Sebagai titik tumpu, kaki biasanya hanya di tempat saja selama motif gerak berlangsung. Kemungkinan gerak yang terjadi pada kaki biasanya hanya berupa ingsutan tumit, gedruk, dan tanjak, yang kemudian digunakan kembali sebagai tempat bertumpu.

Motif gerak berikutnya yaitu milir, biasanya menggunakan langkah kaki, baik lambat maupun cepat dengan segala arah dan putarannya. Langkah yang lambat biasanya hanya menggunakan langkah yang sangat terbatas baik maju, mundur, 
maupun mapan atau nglereg. Sedangkang langkah cepat biasanya menggunakan gerak kaki seperti kicat, kengser, dan trisig. Motif gerak dalam bedhaya Sumreg yang masuk dalam kategori motif gerak milir antara lain: ngendherek, lampah semang ngembat asta, impang ngewer udhet, cathok udhet majeng mundur, wedhi kengser gajah ngoling, pendhapan.

Irama dramatik dalam bedhaya Sumreg terangkai dalam mandeg dan milir-nya motif-motif gerak. Masing-masing motif gerak mengalami pengembangan dalam berbagai variasi, baik dari segi aksi, ruang, dan waktu. Sejumlah motif-motif gerak yang masuk dalam kategori motif gerak mandheg, tetap termuat unsur-unsur gerak milir.

Pengolahan pola lantai dengan motif-motif gerak tari putri gaya Yogyakarta di dalam bedhaya Sumreg terangkai dengan tetap dan teratur. Hal tersebut memang sudah menjadi ciri dari salah satu bentuk tari tradisional keraton Yogyakarta, yaitu simbolis representatif. Pengolahan pola lantai serta motif-motif gerak dalam rangkaian gerak bedhaya Sumreg tidak terkait langsung dengan makna sumreg yang mengandung arti gempar, gaduh, dan hiruk pikuk. Pengolahan pola lantai yang terjadi sekiranya mengacu pada pergolakan politik yang tengah berkecamuk pada waktu itu. Salah satu gambaran pergolakan politik yang terdapat pada bedhaya Sumreg kaitannya dengan konfigurasi atau formasi pola lantai yang dihasilkan oleh kesembilan penarinya seperti ditunjukkan pada gambar di bawah ini, yaitu terletak pada sering ditampilkannya (a) rakit iring-iringan (dari lajur kedua apit nyolongi medal lajur), (b) rakit ajeng-ajengan yang dilanjutkan dengan rakit mlebet lajur, dan formasi (c) medali lajur untuk kembali pada (d) rakit lajur.

Dalam kajian teks bedhaya Sumreg, konfigurasi atau formasi tersebut dilakukan sampai dengan empat kali. Hal ini tampaknya menggambarkan situasi takhta yang penuh intrik di masa kepemimpinan Sri Sultan Hamengku Buwono II sampai dengan Sri Sultan Hamengku Buwono V. Masa-masa kepemimpinan tersebut merupakan masa ketika masih ditampilkannya bedhaya Sumreg sebagai bagian dari rangkaian kegiatan upacara di keraton Yogyakarta.

Masa pemerintahan Sri Sultan Hamengku Buwono II yang naik tahta pada tahun 1792, banyak menimbulkan ketegangan antara pemerintah Belanda dengan keraton. Tujuan pemerintah Belanda sesungguhnya mencari dalih untuk menyingkirkan penguasa kasultanan Yogyakarta pada waktu itu. Pemerintah Belanda menurunkannya dari tahta dengan dalih bahwa Sultan bersikap tidak bersahabat.

Keunikan lain dari teks bedhaya Sumreg ini terdapat dalam rakit gelar, di mana Batak berdiri sendiri dalam rangkaiannya. Batak memerankan Pangeran Mangkubumi yang merupakan tokoh utama dalam bedhaya Sumreg. Dalam formasi ini seolah-olah Pangeran Mangkubumi sedang memimpin persiapan melawan musuh atau perang.

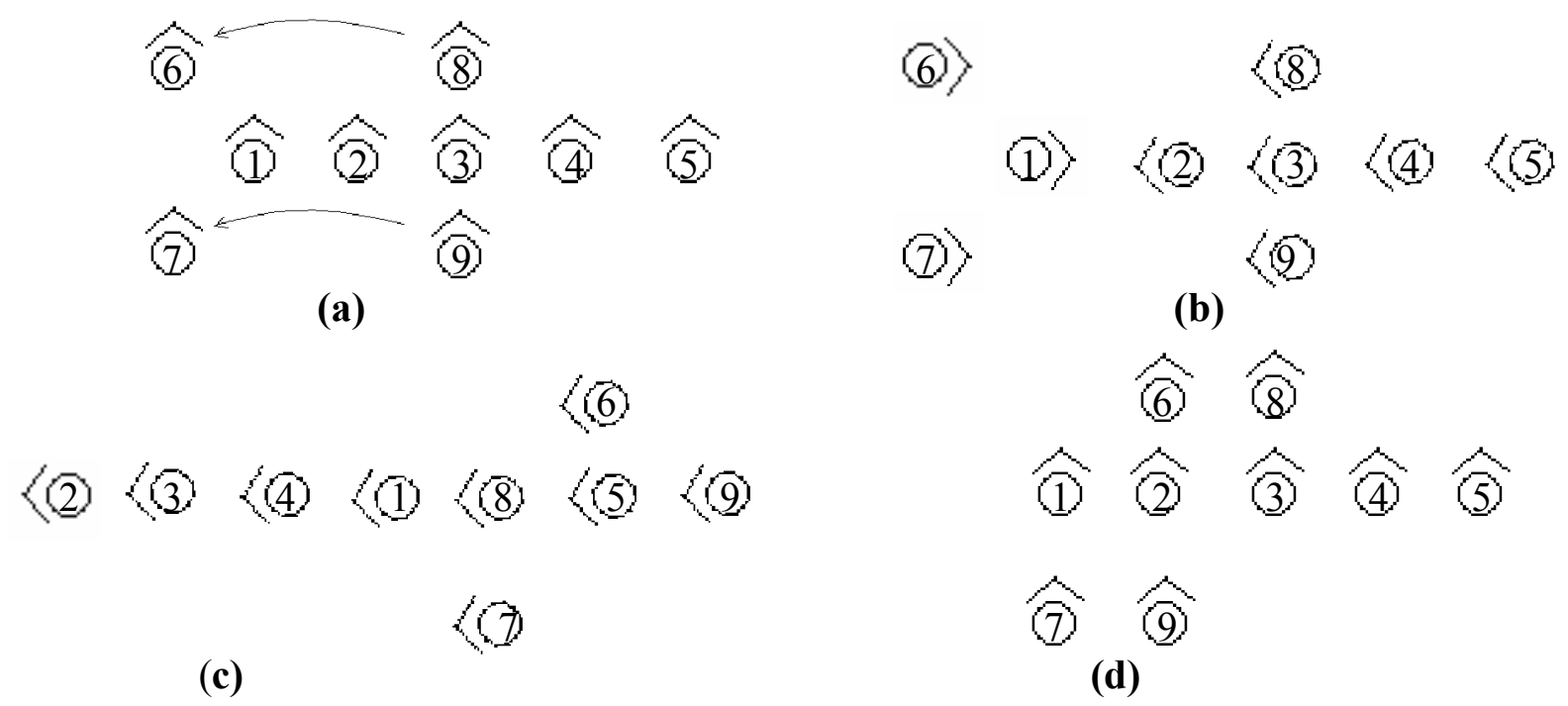

Gambar 4: Pola lantai dalam bedhaya Sumreg 


\section{Iringan}

Iringan atau gendhing, selain untuk mengiringi pertunjukan tari khususnya tari Jawa, juga berfungsi untuk memperkuat atau memperjelas suasana yang ingin diungkapkan. Pemilihan gendhing bedhaya ini disesuaikan pula dengan suasana yang ingin digambarkan di dalamnya. Hal tersebut berlaku pula pada bedhaya Sumreg melalui kandha-nya, di mana keberadaan kandha memiliki makna tersendiri. Kandha yang merupakan monolog berbahasa Jawa yang dibaca oleh pemaos kandha dengan intonasi dan gayanya yang khas. Pada umumnya kandha memuat ringkasan cerita, pencipta, tujuan pementasan, nama tari yang akan dipentaskan, serta kesiapan penari dalam menarikan bedhaya ini. Demikian halnya dalam bedhaya Sumreg ini, disebutkan ceritera maupun tema yang melingkupinya, yaitu campur tangan Belanda dalam pecahnya Mataram melalui perjanjian Giyanti,

Dalam manuskrip dijelaskan bahwa iringan bedhaya Sumreg masih menggunakan pola-pola gendhing lampah bedhayan yang telah disebutkan di atas. Melalui kajian teks ini ditemukan adanya hal yang dirasa unik, dan menjadikan bedhaya Sumreg menjadi istimewa dibandingkan dengan bedhaya yang berkembang saat ini. Keunikan tersebut secara struktural terdapat pada bagian awal (penari masuk ke area pertunjukan) menggunakan Ladrang Endhel, dan pada bagian akhir ( kapang-kapang mundur) menggunakan ladrang Rangu-rangu, Penggunaan ladrangan irama II tersebut sama dengan yang terdapat pada bedhaya Semang.

Secara structural bedhaya Sumreg menampilkan pola-pola gendhing sebagai berikut :

a. Bagian Awal meliputi

1. Ladrang Endhel, digunakan untuk kapangkapang majeng.

2. Setelah suwuk dilanjutkan lagon enem sampai wilet,

3. Kandha

Teks Kandha sebagai berikut :

Sebetbyar wauta, anenggih ingkang kawiyosaken punika

klangenan dalem bedhaya pusaka.

Nanging ingkang kocap ing carios punika sanes-sanes anglaras mangsa kalanipun ingkang jumeneng nata awit kala panjenenganipun Ingkang Sinuwun Kanjeng Susuhunan Hamengku

Buwono ingkang yasa bedhaya pusaka

Wahuta Kanjeng Bendara ingkang

kawiyosaken ing ngarsa dalem

dhasar sami endah warnanira, karengga

ing busana kadya murca kinedhepna

sareng sami majeng ing ngarsa dalem, yen sinawang tindakira lir pendah endhel kabyatireng rengga.

b. Bagian Pokok

1. Kawin Sekar Ageng Girisa kalih pada Yang yang ing sekar asmara, gumebyar retna sang gya

marweng rum munggweng sakantya, pradangga laras rejasa,

sakongas tejaning manik, asawang wulan purnama,

sedheng kapitung sudama, renyep-renyep karya brangta

Tuhu yen putri utama, retnaning dyah amisesa

satya manik ing buwono, sameng sekti mahambara,

sinyegrut ngumbara laya,piturun

kapundyeng kara

kawuwus jayeng tri loka, piturun, winowong Ywang Siwah Boja

2. Gendhing Endhel sampai suwuk

3. Ladrang Narendra Sejati

4. Arang-arangan

5. Ladrang Tejabrangta

6. Ketawang Mijil Widaringtyas sampai suwuk

c. Bagian Akhir

1. Lagon Barang sampai wilet

2. Ketampen Ladrang Rangu-rangu, digunakan untuk kapang-kapang mundur.

Penggunaan bentuk ladrangan irama II pada bedhaya Sumreg dan bedhaya Semang, kiranya merupakan gambaran yang nyata bahwa kedua bedhaya tadi memang hidup di masa yang sezaman. Selain lahir di zaman Mataram, keduanya merupakan warisan keraton Yogyakarta yang dibawa oleh Sri Sultan Hamengku Buwono I 
yang turut ambil bagian dalam pelestarian beksan Mataram dalam periode pertumbuhan.

\section{Penutup}

Kasultanan Yogyakarta sebagai pelestari budaya, banyak menyimpan bahan kajian sejarah berupa naskah kuno atau manuskrip yang merupakan faktor utama atas segala hal yang berkaitan dengan pengaruh mitos, politik, maupun nilai edukatif. Kajian teks manuskrip Serat Kandha Kelangenan Dalem Bedhaya Sumreg ini cukup jelas memaparkan kajian budaya berupa seni pertunjukan yang dilatarbelakangi politik pada saat tarian itu diciptakan, yaitu persaingan antara dua keraton di Jawa, yaitu kasultanan Yogyakarta dan kasunanan Surakarta akibat perjanjian Giyanti tahun 1755. Namun demikian persaingan pada masa lalu yang terletak pada segi politis dan kekuasaan, sejalan pula dengan adanya sisi positif yang mengarah pada pelestarian budaya.

Kajian teks terhadap manuskrip Serat Kandha Bedhaya Sumreg ini telah ditranskripsikan dan ditransformasikan dalam bentuk koreografi. Irama dramatik terangkai dengan tetap dan teratur melalui mandeg dan milirnya motif-motif gerak tari putri gaya Yogyakarta. Masing-masing motif gerak secara tidak langsung mengalami pengembangan dalam berbagai variasi, baik dari segi gerak, ruang, serta waktu. Setiap motif-motif gerak yang ditemukan dalam bedhaya Sumreg, terangkai melalui tatanan gerak yang cukup selektif. Sejumlah motif-motif gerak yang masuk dalam kategori motif gerak mandeg, tetap memuat unsur-unsur gerak milir.

Sebagai ciri dari salah satu bentuk tari tradisi gaya Yogyakarta, yaitu simbolis representatif, ungkapan motif-motif gerak melalui kesembilan penarinya, diharapkan tidak muncul sebagai pribadi dalam penampilannya, tetapi sungguhsungguh bisa mentransformasikan bentuk estetis, dan kemudian dapat berkomunikasi langsung kepada pada para penikmatnya.

Pengolahan pola-pola gendhing iringan yang digunakan secara struktural tetap menggunakan tata aturan baku yang sampai sekarang lazim disebut dengan lampah bedhayan. Demikian juga pengolahan pola lantai dasar serta motif-motif geraknya masih tetap mengacu pada tari bedhaya pada umumnya.

Ungkapan seni yang berbentuk bedhaya Sumreg ini mengandung misi yang positif, karena bisa dipakai sebagai langkah awal untuk membuka tabir misteri dari bentuk tari yang dianggap pusaka tersebut. Penemuan jejak masa lalu berupa hasil budaya ini, merupakan fenomena yang bernilai tinggi. Sudah barang tentu tafsir kebudayaan yang mengarah pada penelusuran masa lalu tersebut tidak bisa meninggalkan faktor kesejarahan. Dalam upaya penelusuran ini, hanya dengan sejarah Mataramlah maka menjadi mungkin bagi para sejarawan untuk membahasnya dengan keyakinan yang lebih besar.

\section{Kepustakaan}

Ahimsa- Putra, Heddy Sri.1998. "Sebagai Teks Dalam Konteks:Seni Dalam Kajian Anropologi Budaya", dalam Seni: Jurnal Pengetahuan dan Penciptaan Seni, Edisi VI/01, Yogyakarta.

Artha, Arwan Tuti, Heddy Sri Ahimsa-Putra. 2004. Jejak Masa Lalu Sejuta Warisan Budaya. Yogyakarta: Kunci Ilmu

Brakel-Papenhuyzen, Clara. 1992. The Bedhaya Court Dance of Central Java. Leiden: E.J. Brill

Purwadi. 2001. Babad Tanah Jawi: Menelusuri Jejak Konfli. Yogyakarta: Pustaka Alif.

Ricklefs, M.C. 2002. Yogyakarta di Bawah Sultan Mangkubumi 1749-1792 Sejarah Pembagian Jawa. Yogyakarta: Mata Bangsa

Soedarsono, R.M. Wayang Wong: Drama Tari Ritual Kenegaraan di Keraton Yogyakarta. Yogyakarta: Gadjah Mada University Press

Wibowo, Fred, ed.. 1981. Mengenal Tari Klasik Gaya Yogyakarta. Yogyakarta: Dewan Kesenian Propinsi DIY

Yayasan Siswa Among Beksa, "Catatan Tentang Beberapa Perkumpulan Tari Klasik Gaya Yogyakarta di Luar Keraton", dalam Fred Wibowo, ed.. 1981. Mengenal Tari Klasik Gaya Yogyakarta. Yogyakarta: Dewan Kesenian Propinsi DIY. 